\title{
New product development with the innovative biomolecular sublingual immunotherapy formulations for the management of allergic rhinitis [Corrigendum]
}

Frati F, Cecchi L, Scala E, Ridolo E, Dell'Albani I, Makrì E, Pajno GB, Incorvaia C. Biologics: Targets and Therapy. 2014;8:221-226.

On page 223, Figure 1 should be replaced with the revised version as shown below:

On page 224, line 4 in the left column, "many" should be replaced with "all".

On page 224, line 7 in the left column, "but only the major allergen Phl p 5 is measured in $\mu$ g" should be replaced with "such as group 1 and group 5 allergens (Figure1, Table 2)".

On page 224, line 9 in the left column, the reference to "(Figure 1)" should be removed.

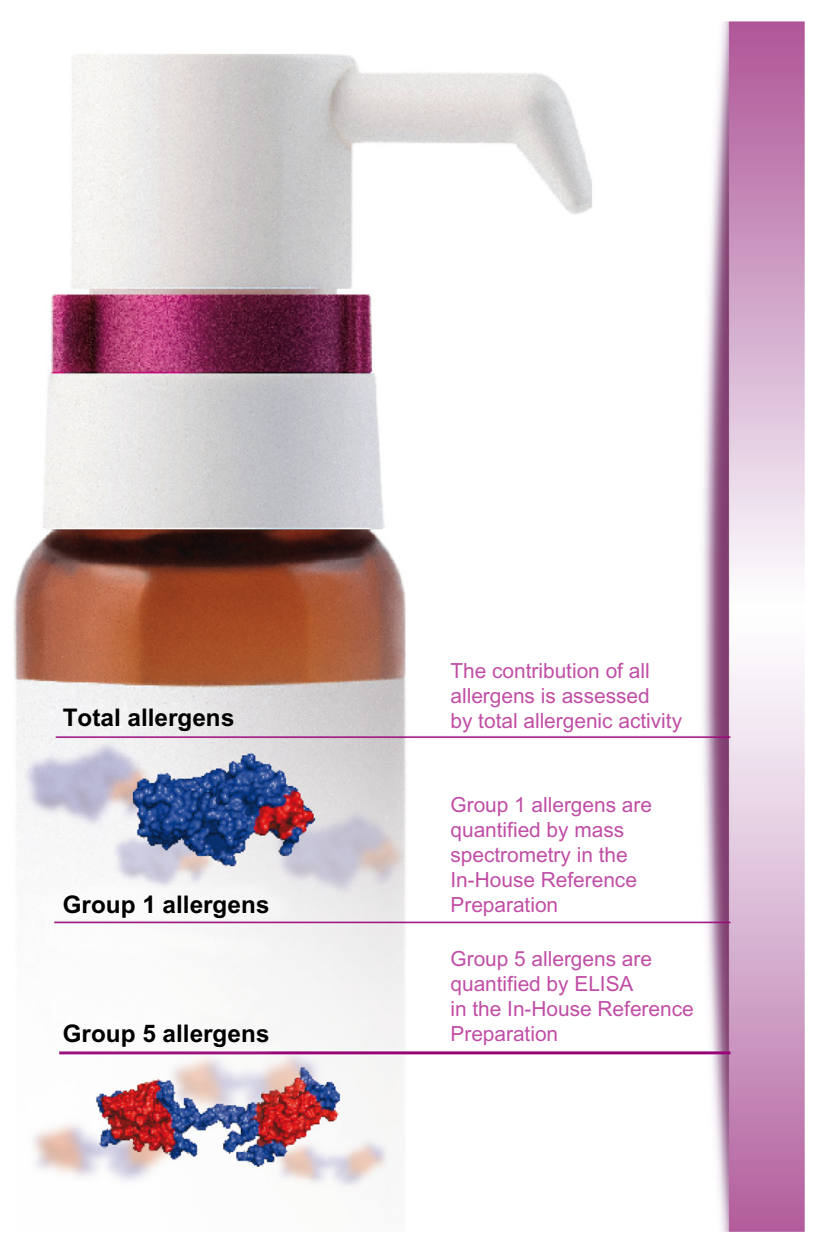

Figure I The molecular profile of Staloral biomolecular grasses.

\section{Publish your work in this journal}

Biologics: Targets \& Therapy is an international, peer-reviewed journal focusing on the patho-physiological rationale for and clinical application of Biologic agents in the management of autoimmune diseases, cancers or other pathologies where a molecular target can be identified This journal is indexed on PubMed Central, CAS, EMBase, Scopus

and the Elsevier Bibliographic databases. The manuscript management system is completely online and includes a very quick and fair peerreview system, which is all easy to use. Visit http://www.dovepress. com/testimonials.php to read real quotes from published authors. 